\title{
A FRAMEWORK FOR APPLICATION OF RENEWABLE ENERGY IN URBAN WATER SYSTEMS
}

\section{Jure Margeta}

Scientific paper / Znanstveni rad

(Received: 21 Mart 2018; accepted: 24 May 2018)

University of Split, Faculty of Civil Engineering, Architecture \& Geodesy, Full Professor

Corresponding author: margeta@gradst.hr

\begin{abstract}
This paper presents possible concepts of using renewable energy sources (RESs) in urban water systems (UWSs). The hydro and biomass energy generated by UWSs are typical renewable sources of energy, but these have limited capacity. Solar and wind energy sources are standard global RESs characterized by large capacity and intermittent production. However, technological challenges associated with the use of the sun and wind means that these sources cannot directly and continuously supply a UWS with electric energy. Thus, it is necessary to hybridize them with conventional sources through the electric energy grid system or the use of electric energy storage (EES) including pump storage hydroelectric (PSH) plants. The analysis presented in the paper determined that green energy is possible and relatively easy to implement in a UWS. The use of RESs contributes to the straightening of urban energy sustainability and the reduction of $\mathrm{CO}_{2}$ emissions from UWSs.
\end{abstract}

Keywords: sustainability; urban water system; $\mathrm{CO}_{2}$ emissions, renewable energy sources; photovoltaic pumping; sustainable cities

\section{OKVIR ZA KORIŠTENJE OBNOVLJIVIH IZVORA ENERGIJE U URBANOM VODNOM SUSTAVU}

Sažetak: U radu se objašnjava mogući koncepti primjene obnovljivih izvora energije u urbanom vodnom sustavu (UVS). Hidro energija i energija iz organskog mulja su zelena/obnovljiva energija koju generira UVS, ali ograničenog kapaciteta. Solarna i energija vjetra su pak globalni izvori zelene energije neograničenog kapaciteta. Na žalost njhova proizvodnja nije stalna već sa prekidima. Zbog toga je njihova šira primjena u UVS još problematična. Kako bi se osigurao kontinuitet opskrbe energijom ove izvore energije treba integrirati sa konvencionalnim izvorima energije kroz električnu mrežu ili koristiti neki spremnik energije, uključujući i reverzibilnu hidroelektranu. Provedenom analizom koja se daje u radu pokazuje se da je relativno lako koristiti zelenu energiju u UVS uz manje dogradnje UVS-a. Korištenje zelene energije jača se energetska održivost urbanih sredina te smanjuje ispuštanje stakleničkih plinova iz UVS.

Ključne riječi: održivost; urbani vodni sustav; emisija $\mathrm{CO}_{2}$; obnovljivi izvori energije; solarno pumpanje; održivi gradovi 


\section{INTRODUCTION}

In an increasingly urbanized world, it is necessary to plan and manage cities in order to sustain them and to contribute to local, regional, and global sustainable development. This also applies to urban infrastructures and services, including urban water systems (UWSs) [1]. The challenge of urban development is to absorb urban growth while solving the environmental and social equity problems arising from economic and physical concentration. This primarily involves the development of urban infrastructures that enable sustainable living in a densely built environment. Solving the environmental problems can help to reduce the global problems of environmental health and industrialization, as well as most green problems [2]. Urban water systems, water supply and sanitation, drainage and flooding prevention, and pollution controls are infrastructures that significantly reduce environmental health problems and thus contribute to the sustainability of cities and sustainable development in general.

UWS contribute to climate change as a result of their consumption of energy derived from carbon-based fuels and biochemical processes that directly generate fugitive greenhouse gases. The carbon equivalent of energy produced by different fossil fuel power plants is approximately $0.70-0.9 \mathrm{~kg}$ of $\mathrm{CO}_{2}$ emitted per $\mathrm{kWh}$ of energy produced. Therefore, efforts are being made to reduce electricity consumption in the UWS, as well as energy derived from carbon-based fuels. This is achieved in various ways, and one way is by using renewable resources [3]. Water is a basic resource of UWSs, and the other key resource for the operation of UWSs is energy. Energy is necessary to bring water from water sources to homes and to take wastewater from towns back to water resources or to recycle, as shown in Figure 1. UWS activities are energy intensive and in general grow as a city and total water consumption grow. Approximately $60-80 \%$ of municipal water and wastewater costs are solely for electricity [4].

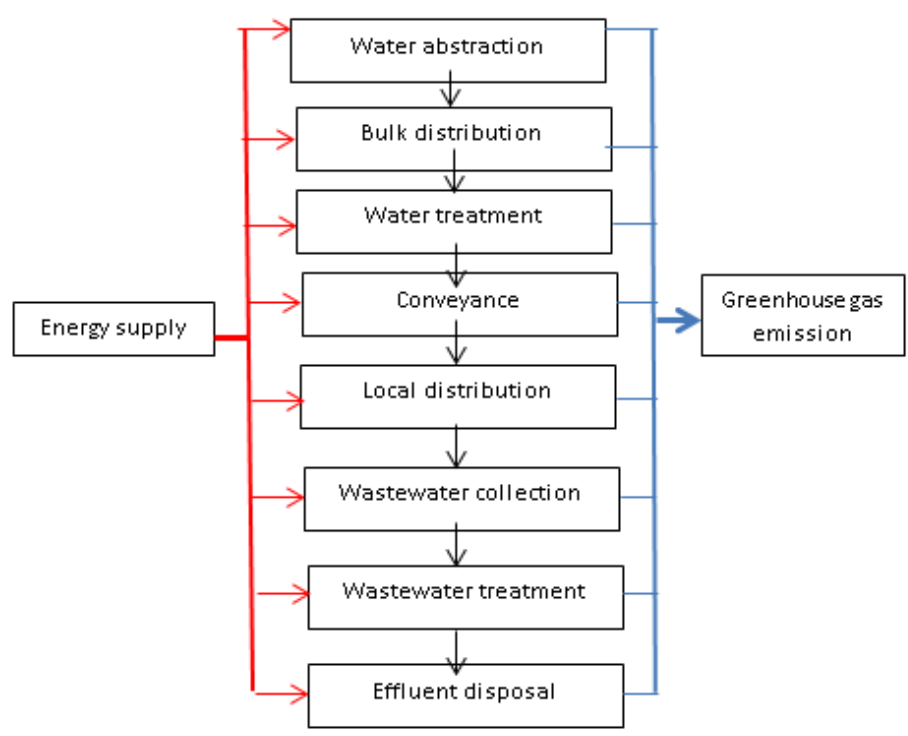

Figure 1 Urban water system elements: energy supply (electric, thermal, transport, etc.) and greenhouse gas emissions

Electric energy consumption in a UWS depends on the characteristics of the urban environment and the UWS and ranges from 100-300 kWh/cap per year. Local conditions including topography, water sources, and water use have a major influence on energy use values. This means that a UWS is a significant source of $\mathrm{CO}_{2}$ emissions as a result of the use of electric energy from fossil fuels. The operation of water supply and wastewater systems is responsible for emission of approximately $25-45 \mathrm{~kg} \mathrm{CO}_{2}$ e/cap per year [5].

In analyzing urban water system components, energy use, and associated $\mathrm{CO}_{2}$ emissions, the pumping of potable water from a source into service reservoirs is most frequently the largest energy consumer $\left(2-4 \mathrm{kWh} / \mathrm{m}^{3}\right)$, while raw water abstraction and pumping is the second largest $\left(0.4-0.8 \mathrm{kWh} / \mathrm{m}^{3}\right)$. Drinking water treatment

Margeta, J 
facilities may be significant consumers of energy, depending on the purification technology. The highest energy consumption is in the case of using desalination (reverse osmosis of $2.5-4.5 \mathrm{kWh} / \mathrm{m}^{3}$ ).

Similar but lower energy consumption also applies to urban wastewater system pumping in order to collect wastewater for a wastewater treatment plant (WWTP) (collection and treatment of $0.4-1.5 \mathrm{kWh} / \mathrm{m}^{3}$ ) [6]. Namely, the total head of wastewater pumps is much smaller than in the water supply system, but the efficiency of the pumps is also smaller. Therefore, the energy consumption is significant. Generally, there is a small energy input to the storm water system. In addition to energy efficiency measures, a reduction in energy costs and $\mathrm{CO}_{2}$ emissions is generally achieved by shifting energy consumption as much as possible to off-peak periods, and if possible by the use of renewable energy sources (RESs). The frameworks of the possible use of RESs are elaborated below.

The use of RESs in a UWS is a more complex problem than with other consumers. The operational safety of a UWS is extremely important for life in cities. A $99 \%$ reliability rate of water supply is required. Therefore, the high reliability of the energy supply is also necessary. This is solved in a classic approach by the use of a diesel generator. One possibility is the use of local energy sources such as RESs. However, if a local RES is used as the main source of energy, securing the reliable operation of a UWS is a significant challenge for engineers.

\section{ADVANTAGES AND DRAWBACKS OF USING CERTAIN RES IN UWS}

Wind and solar plants, small hydroelectric plants, biomass, and geothermal are RESs generally suitable for use in UWSs. This is shown in Figure 2 [7].

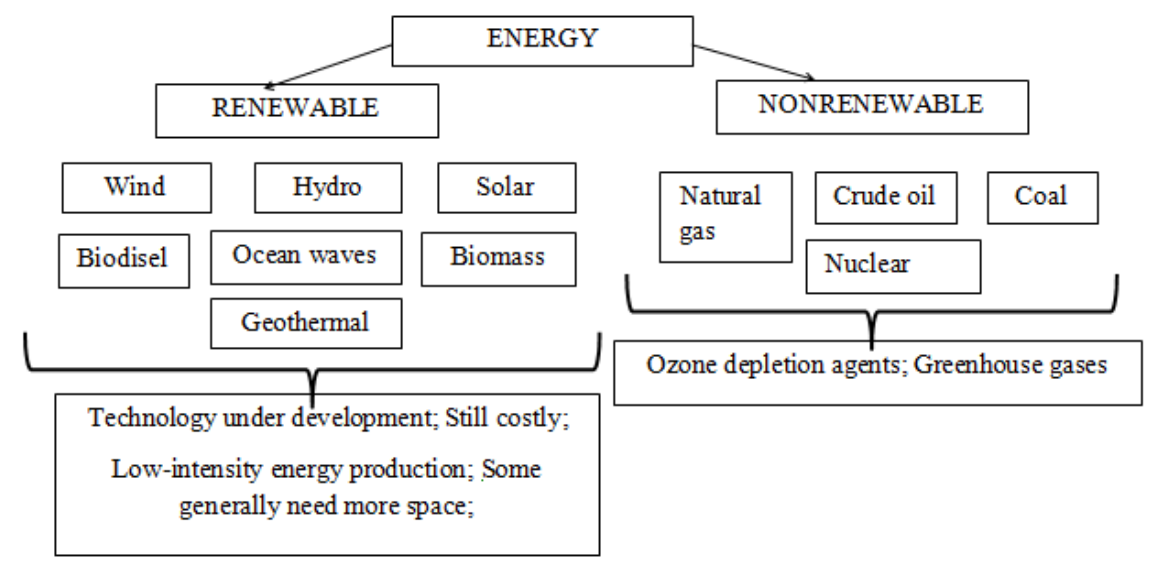

Figure 2 Energy sources and basic characteristics (modified from [8])

This raises the question of whether and which RES may be suitable for a UWS and how it can be used: as a stand-alone energy production system for different users of the UWS (pump stations, treatment plants, etc.), or by connection to the energy grid network (local or/and regional).

The current technological development of RESs is not yet complete, and their use is not a productive alternative to conventional energy sources. The problem is that the most important RESs such as solar and wind energy cannot be directed toward energy consumption, and the remaining stable and controllable sources such as hydro, geothermal, biomass, and others. Solar and wind energy sources are not constant because wind generators produce energy only when an appropriate wind is blowing, and solar generators can only be used during periods of sunlight. Therefore, these RESs cannot produce energy continuously and supply a consumer, so it is necessary to hybridize them with conventional sources through the electric energy grid system or the use of Electric Energy Storage (EES), all in order to ensure the high safety of UWS operation. In this way, EES has significant role in the realization of green energy supplies to UWSs. Numerous technologies of energy storage are known today (batteries, flywheel, pressure vessels, etc.), which differ in size, energy storage costs, efficiency, lifetime, costs per cycle, etc. [8]

There are several alternative solutions that can be implemented in order to use RESs in UWSs. The possible solutions are presented in the paper. RESs that, owing to their global distribution, can be widely used in 
UWSs are wind and solar energy sources. Wind energy sources are available at numerous locations with different energy potential. A wind development project starts with the analysis of a windy site, as the economics of wind power depend strictly on the wind velocity and duration during the year. One thing is certain: there is no wind location close to the UWS that is sufficiently reliable and blows at adequate speed throughout the entire year or from year to year. Interruptions of production are possible while the occurrence and duration are unpredictable. This characteristic of wind turbines is actually the most significant problem in local use as an energy source for a UWS. Uncertainty in electric energy production is too high for direct UWS application.

On the other hand, solar energy is available almost every day, but with different irradiation and durations of sunlight depending on location and climate. The daily quantity of available solar energy depends on the season and on the current cloudiness. Thus, uncertainty in electric energy production is generally smaller than in the case of a wind turbine. This energy is free, available at each location where people live. In principle, solar power can be generated anywhere on earth, but with different productivity and with possible brief interruptions owing to current cloudiness. Owing to these characteristics, a more promising solution for renewable energy supply is the use of solar energy. Two types of solar generators in use are photovoltaic (PV) plants and solar thermal (ST) plants. PV plants turn sunlight directly into electric energy [9]. They are very simple plants and are easy to use. ST plants are more complex plants. They use the sun as the source of heat. The heat is captured, concentrated, and used to drive heat engines and electric generators. These plants are mostly based on existing power station technology. To be able to produce power, ST requires a classical fuel backup and water withdrawal. Photovoltaic systems produce energy during sunny days, supply customers, and charge the batteries that provide electricity during the night and during periods of insufficient sunshine. Other RESs that can have applications in a UWS are geothermal, biomass, and small hydroelectric plants. These are site-specific sources of energy that are not as widely available as solar energy. Geothermal energy is obtained from the earth's internal heat and can be used for generating steam to run steam turbines and electric generators [7]. A prerequisite for the installation of this energy source is the existence of favorable geothermal conditions in or near cities.

Biomass includes any organic matter that is available on a renewable or recurring basis. Biomass energy can be derived from gaseous, solid, or liquid biomass. As it is renewable and abundant; biomass has the potential to offer a diverse supply of reliable, affordable, and environmentally sound chemicals and energy to replace fossil fuels. Biomass includes energy crops and trees, agriculture crop residuals, animal manure, and other organic waste materials, as well as sludge from wastewater treatment plants. The production of biomass for providing electric energy solely for the needs of a UWS is unrealistic, except in extraordinary situations. Hydroelectric energy is a classic and economically advantageous source of energy and power, but is often unavailable locally or in cities.

\section{$3 \quad$ INTERNAL GREEN ENERGY FOR UWS}

The UWS itself is a potential source of biomass and hydroelectric energy that can be classified as internal green energy sources. Biomass energy (gaseous biomass) has long been used in UWSs and wastewater treatment plants [10]. Wastewater contains a certain amount of energy that may be recovered. Typical urban wastewater has a COD value of approximately $0.5 \mathrm{~kg} / \mathrm{m}^{3}$ [11]. Based upon a theoretical energy production of $1.47 \times 10^{7}$ joule per kilogram of $\mathrm{COD}$ oxidized to $\mathrm{CO}_{2}$ and $\mathrm{H}_{2} \mathrm{O}$, the energy density of wastewater is $0.47 \times 10^{7} \mathrm{~J} / \mathrm{m}^{3}$ [12]. Experimental results were estimated to be $1.68 \times 10^{7} \mathrm{~J} / \mathrm{m}^{3}$ for wastewater mixed with domestic wastewater and industrial wastewater, and $0.76 \times 10^{7} \mathrm{~J} / \mathrm{m}^{3}$ for pure domestic wastewater [13]. Therefore, a fair estimation of the theoretical energy density in wastewater is on the order of $10^{7} \mathrm{~J} / \mathrm{m}^{3}$. The electric energy consumed for treating per $\mathrm{m}^{3}$ wastewater using traditional anaerobic sludge digestion techniques is approximately $2 \times 10^{6} \mathrm{~J} / \mathrm{m}^{3}$ of electric energy [11]. Therefore, the theoretical energy density in wastewater is five times that of the energy consumed to treat the wastewater. The real values are much smaller owing to the heat dissipation during energy transfer from various reducing matters to methane. Considering that only approximately $35 \%$ of the chemical energy of methane can be converted into electricity through combusting processes, the overall energy recovery efficiency is approximately $28 \%$. This number can potentially increase with various innovative processes up to $40 \%$. Thus, it is possible to make the wastewater treatment plant self-sustainable for the energy demand by applying anaerobic sludge treatments. Methane gas can be stored and used as needed, and the production of

Margeta, J 
electric energy can be managed. This is a proven technology along with its economy. However, burning biogas still emits $\mathrm{CO}_{2}$.

The UWS itself is a potential source of local hydro energy that can be used, if available [14]. It is mostly surplus potential hydraulic energy in the water supply. Such an energy potential does not exist in an urban wastewater system. The water and pressure at a particular location on the pipeline system can be used in the same proportion as available in the pipes. This system is known as a run-of-river plant with a flow turbine that can be put directly into the pipe [15]. Production is based on the exploitation of the available surplus of hydropower in the water supply system. The available hydropower potential varies considerably throughout the day, depending on the current consumption of water in the water supply system. The available pressure is inversely proportional to the flow, as shown in Figure 3. In well-designed systems that lack high pressure in the distribution network, the available hydro-energy potential for electricity production is significant mainly in off-peak periods. In systems that have unnecessarily large pressure in the distribution network, the potential is significantly higher throughout the day.

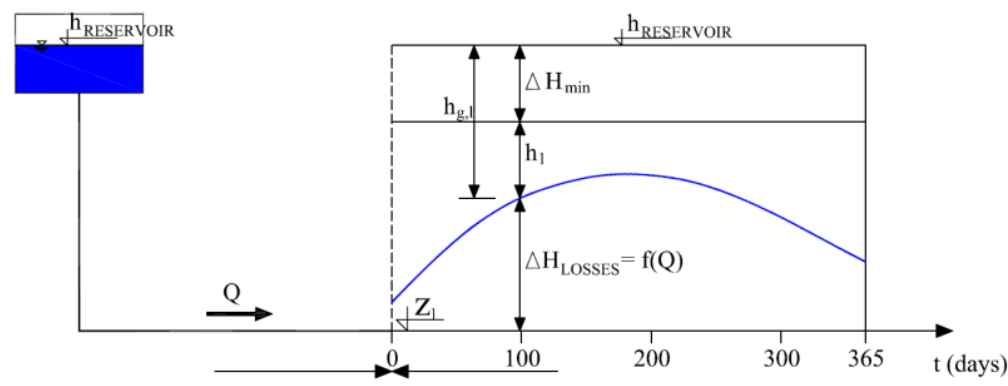

OUTPUT SUPPLY PIPELINE WATER SUPPLY NETWORK

a) Generalized relation between pressures in system during the year

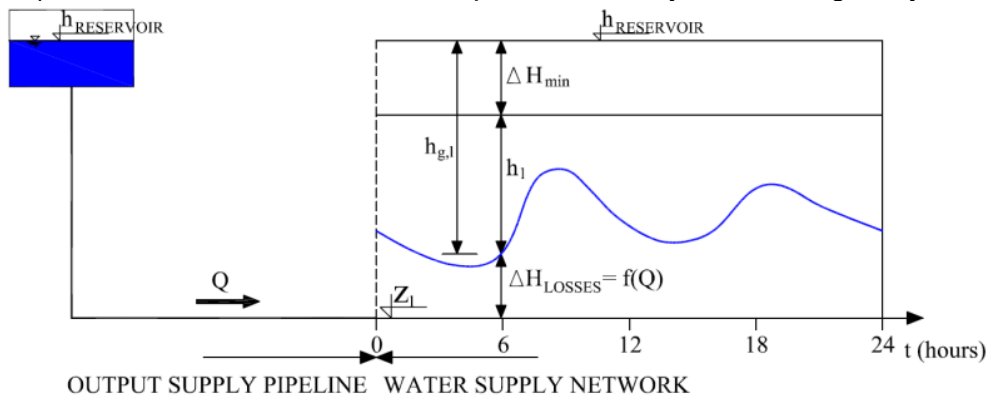

b) Generalized relation between pressures in system during the day

Figure 3 Generalized relations between pressures in system as function of time

In Figure 3, $h_{R E S E R V O I R}$ is the water level in the reservoir, $\Delta H_{\text {min, }}$ is the minimum required pressure height at the energy production point (hydrant $\approx 25 \mathrm{~m}$ ) at location I in the water network, $\Delta H_{\text {losses, }}$ is the pressure loss at location I as the result of water movement in the system from the reservoir to location I, Z, is the pipe level at given location I, and $h_{1}$ is the available gross pressure altitude at location I in the water network. The potential energy is proportional to the surface area above the curve of flow in the system, as shown in Figure 3. As a result, these surfaces are useful indicators of possible energy potential in the system. The average annual potential hydro energy $h_{g}$ average annual is

$h_{g, \text { mean,annual }}=\left[\left(\sum_{i=1}^{365} h_{g, \text { mean,daily }(i)}\right) / 365\right]^{2}$

where $h_{g}$ average daily(i) $=$ average daily energy potential for the diagram of hourly water consumption in the $i$ th day (Figure $3 \mathrm{~b}$ ), and $h_{g}$ average annual = average annual energy potential for the diagram of annual water consumption (Figure 3a).

The possible generation of electric power at a particular location in the water system is $P=\gamma \cdot h \cdot Q \cdot \eta(\mathrm{kW})$, where $h$ is the net head corresponding to the water supply flow rate $Q, \gamma$ is the specific weight of the water, and $\eta$ is the production efficiency. Net hydro energy $E_{\text {neto }}$ that can be generated will be smaller depending on the type of 
turbine and the total efficiency of the hydroelectric plant $\eta_{H E .} E_{\text {neto }}=\left(V_{\text {year }} \cdot h_{g, \text { mean,annual }} \cdot \eta_{H E}\right) / 367$ (kWh/year).

Hydroelectric energy production is generally very limited and insufficient for most UWS needs. However, the use of these energy potentials is particularly advantageous if they are applied to water loss control in the system. By installing turbines, the water pressure downstream in the system is reduced, and water loss occurs. This will reduce energy, water resource exploitation, and $\mathrm{CO}_{2}$ emissions, and thus, it will contribute to sustainability objectives.

In summary, it can be concluded that the internal green energy sources in a UWS (biomass and hydro) are small sources of limited capacity to meet more significant needs of the UWS, or for a self-sustainable UWS for energy demand. Therefore, external green energy sources are necessary.

\section{EXTERNAL GREEN ENERGY FOR UWS}

The most promising external source of a RES for a UWS is solar energy, especially PV technology. The sun continuously provides the earth with a significant amount of energy equally distributed all over the world. It is clean, abundant, and a more and more economical energy source, as shown in Figure 4.

Since 1980, the cost of silicon modules (the finished packages of cells that are put in service) has fallen by $90 \%$ [16]. The rapid increase in solar-to-electric power conversion efficiency (currently $17.9 \%$ certified) in less than five years makes it highly promising for large-scale commercialization [17].

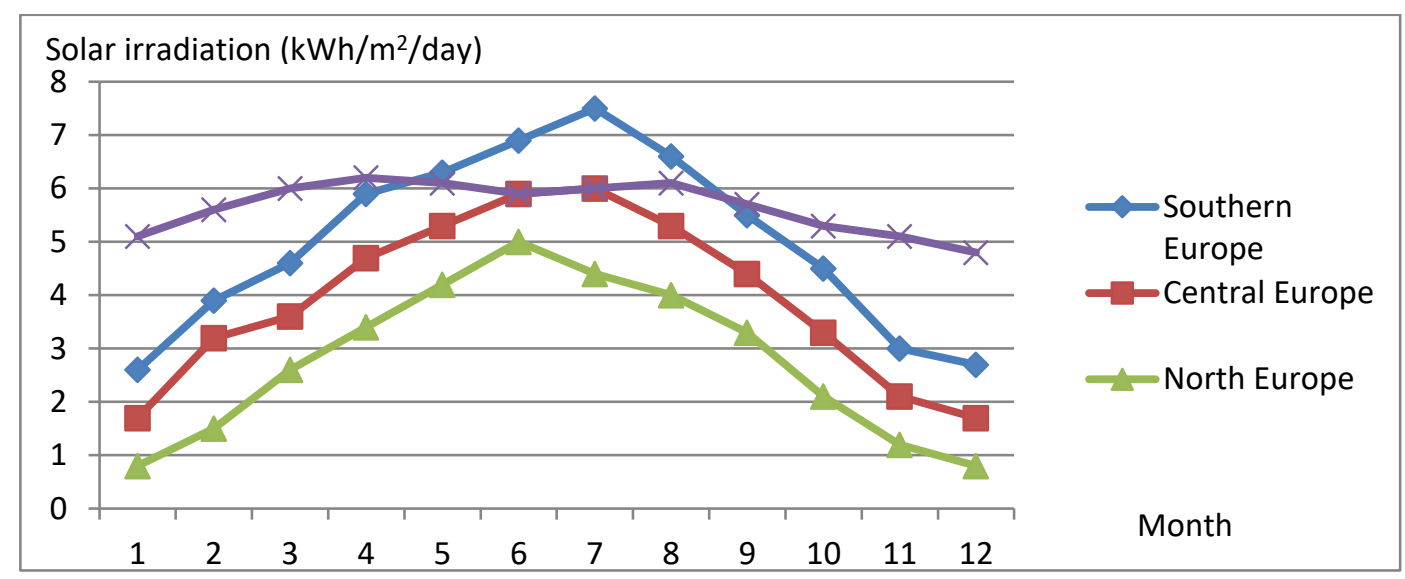

Figure 4 Solar irradiation (kW/ $\mathrm{m}^{2}$ day) in Europe and Caribbean [15]

Solar radiation (and in this regard, the climate of a region) are closely linked to the regime of water consumption of the region, as shown in Figure 5.
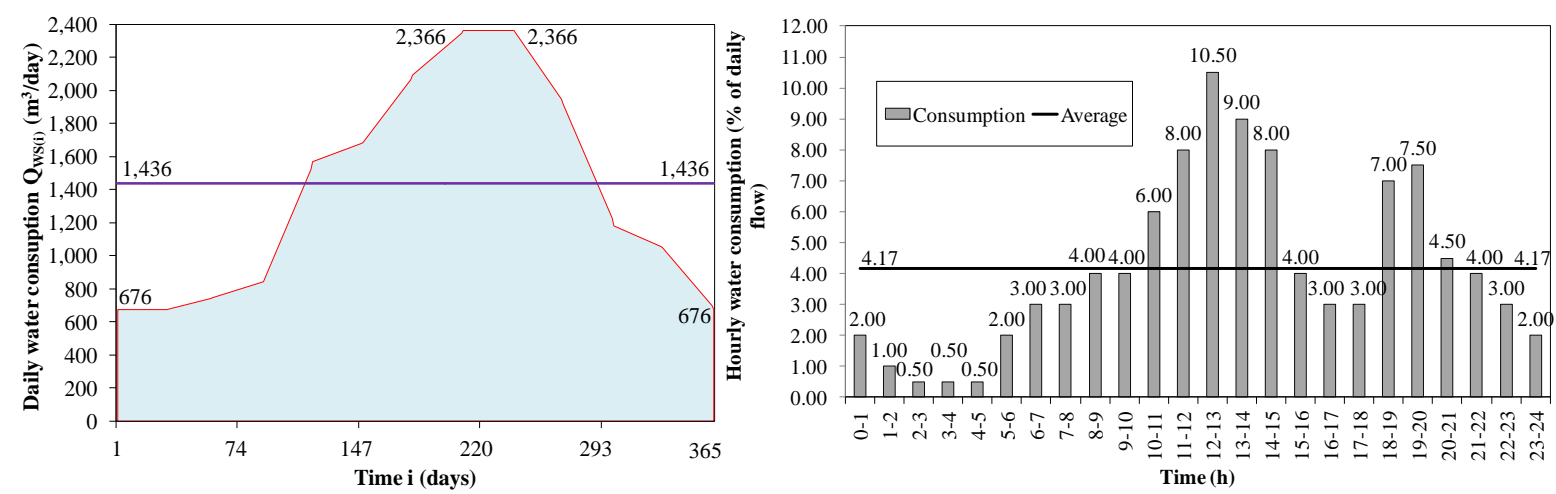

a) Daily water demand during year

b) Hourly water demand during typical day

Figure 5 Example of water demand pattern in tourist area

\section{Margeta, J}


Figure 5 presents typical water demands in a coastal settlement with a population of 8970 in Croatia using a specific water consumption of $160 \mathrm{~L} /$ capita/day [18]. It is known that in the warmer periods of the year and days, i.e., periods of stronger solar radiation, the water consumption is higher, and therefore the electric energy consumption in the UWS is higher. Settlement most of the water (approximately $80 \%$ ) is consumed during the day, from 7 am to $8 \mathrm{pm}$, i.e., during periods of solar radiation. In this period, the greatest part of wastewater, i.e., biomass, is also generated. It can be concluded that the available solar energy and electricity needs in a UWS are naturally linked. Owing to this, the sustainability of the energy supply of a UWS should be based mainly on solar energy as a major external energy source and biomass-methane gas as a major internal energy source. Methane gas can be stored in tanks and used as needed, and the production of electric energy can be controlled and solar electric energy can be stored in an EES and used as needed. Thus, the required reliability of an electric energy supply can be satisfied.

It is important to stress that water withdrawal is not necessary for solar energy conversion into electric energy by a PV generator. A prerequisite for the continuous use of solar energy is the implementation of EES: mechanical, electrical, chemical, and electrochemical. For the time being, these EESs are expensive facilities and represent a practical solution for smaller consumers, but not yet for larger consumers such as UWSs. In a UWS, water in reservoirs is being a possible solution if the appropriate integration of solar energy with UWS water storage is implemented. In a water supply system, storage accumulates raw water and service reservoirs for drinking water. In a wastewater system, as well as a surface water and drainage system, water is stored in retention basins (RBs) of different designs and purposes. There are RBs of pump stations, at overflow, in front of wastewater treatment plants, and retention basins of storm water. By regulating the flow of water, these storage methods essentially regulate and balance energy in the UWS. All these water and wastewater storage methods can, in principle, be integrated with PV generators in order to sustain renewable energy use. Integration can be accomplished with existing UWS storage and new purpose-built methods for the maximum use of solar energy [18].

A solar water pumping system is the simplest and safest way to use solar energy in a UWS, as shown in Figure 6 [18]. A pump station operates when solar energy is available, and pumps water into a reservoir that balances the inflow and outflow of water in the design period. This solves the problem of continuity and security of the water supply. Water storage can have a reserve volume for all incidental situations.

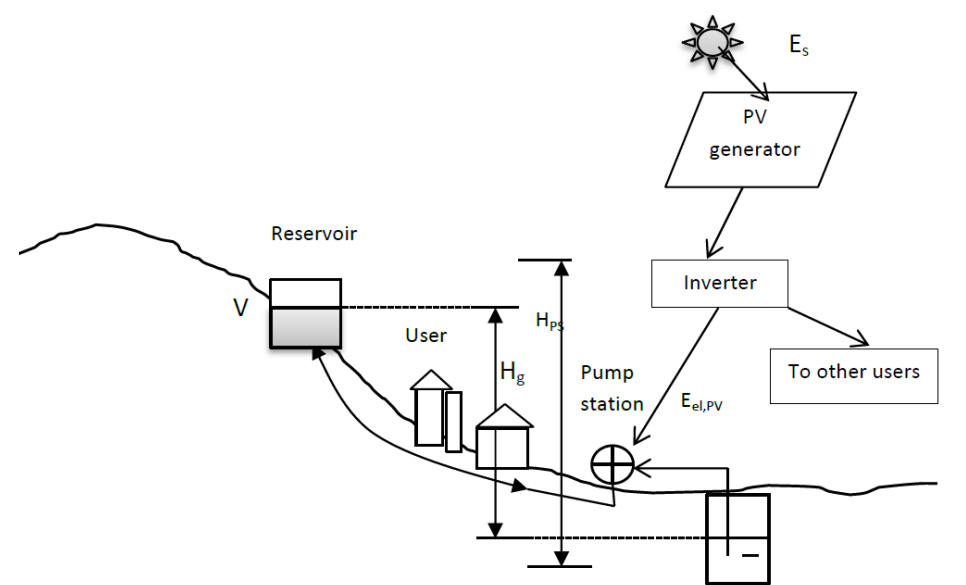

Figure 6 Examples of integration of PV generator with UWS infrastructure

In this way, water storage replaces the EES and provides a continuous supply of water to the system. In a solar pumping system, the PV power plant receives energy from the sun. This energy is converted into work (mechanical energy) of the pump, which increases the internal energy of the fluid or water volume at the particular elevation needed. Part of the energy is lost in this process. Losses are highest in the PV generator, and refer to the conversion of solar to electric energy (approximately 85\%) [19], while losses are significantly lower in the pump system (10-15\%) and mostly relate to losses in friction owing to fluid movement in the system. Water in the reservoir/chamber is available potential energy for the water flow in the water supply network. For a given

Margeta, J 
nominal power $P_{e l, P V}(\mathrm{~kW})$, the possible pumping volume of water $V_{P S(t)}\left(\mathrm{m}^{3}\right)$ in time period $t$ into the reservoir is [20].

$$
V_{P S(t)}=\frac{\eta_{P V} \eta_{M P I} E_{\mathrm{S}(t)}}{2.72 H_{P S(t)}} P_{\mathrm{el}, P V}
$$

where $H_{P S(t)}(m)$ is the total head, $V_{P S(t)}\left(m^{3}\right)$ is the water volume to be pumped by the PV generator in time stage $t$ $\left(m^{3}\right), \eta_{P V}$ is the average efficiency of the PV generator, $\eta_{M P I}$ is the average efficiency of the motor pump unit and inverter, and $E_{S(t)}\left(\mathrm{kWh} / \mathrm{m}^{2}\right)$ is the average daily solar energy available for energy production, all in time step t. The cell area $\mathrm{APV}_{\mathrm{PV}}\left(\mathrm{m}^{2}\right)$ of $\mathrm{PV}$ collectors can be calculated by [20]:

$A_{P V}=P_{e l, P V} /\left(1000 \eta_{P V}\right)$

Solar irradiation is more or less available each day for approximately $8-12 \mathrm{~h}$. Water is pumped in the period when consumption is the highest, so in principle it does not significantly increase the volume of the service reservoirs. During the day, all amounts of water that are consumed during the night should also be pumped, and they are significantly less than the daily amount, as shown in Figure 6 . In any case, the service reservoir volume should be smaller than that when water is pumped only at night owing to the use of cheaper energy sources. Spare volume can be provided in the reservoir for disruptions in the energy and water supply.

The volume of the reservoir is determined by the inflow and outflow time series in the designing period:

$\mathrm{V}_{(t)}=\mathrm{V}_{(t-1)}+\mathrm{V}_{\mathrm{PS}(t)}-\mathrm{V}_{\text {OUT(t) }}-\mathrm{V}_{\text {loss(t), }}$, where increment $t$ assumes the values $t=1$ to $N(N$ is the total number of time stages, e.g., days or hours); $V_{(t-1)}$ and $V_{(t)}$ are storage volumes in the $(t-1)$ and $t$ periods, respectively $\left(\mathrm{m}^{3} / t\right) ; V_{P S(t)}$ is water pumped by the PV power plant in period $t\left(\mathrm{~m}^{3} / \mathrm{t}\right) ; V_{\text {OUT(t) }}$ is water discharged from the storage/reservoir into the system; and $V_{\text {loss }(t)}$ is the loss from storage in period $t\left(\mathrm{~m}^{3} / \mathrm{t}\right)$. This is an example of water pumping into the service reservoir of a water supply system. Water discharge $V_{\text {OUT(t) }}$ is the urban hourly water demand during the day, and is generally known and prescribed in the process of water supply system design, as shown in Figure 5. Water as well as the wastewater variation $\left(V_{\text {OUT }(t)}\right)$ depend on the size of the settlement and activities there.

Water pumped by the PV power plant $V_{P S(t)}$ varies as a result of solar energy variation. Daily insolation varies considerably from day to day, depending on the weather conditions (cloudiness) on the day in question. However, the general trend of changes is stable throughout the year (mean monthly values) and in accordance with the climatic features of the area, as shown in Figure 4. The pattern of sun irradiation is also generally very stable during the day. It can be disrupted depending on daily cloudiness.

Owing to this, the integrated system "PV generator-pump station-reservoir-water demand" should be accordingly sized in order to achieve the required level of operational reliability during the entire planning period [18]. The critical period for operation of the system is the period in which the relationship between the necessary hydraulic energy $E_{S}$ and the available solar energy $E_{H}$ is the least favorable in relation to the function of the system "PV generator-pump station-reservoir-water demand." This relationship determines the minimum required PV generator power, and the pump station and reservoir volume during the planning period. The balancing period $(t)$ is usually 1 day $(24 \mathrm{~h})$ but can be extended to additional days. Extending the balancing period to several days reduces the variability of the available insolation $E_{s(t)}$ because extreme values are reduced, and thus the variability of the total solar radiation in the period $(t)$ is reduced as well. This is a known law of natural time series.

The necessary daily $E_{H}$ does not change significantly, and therefore the ratio $E_{S} / E_{H}$ increases, thus reducing the required installed capacity of the PV generator [18]. In all other periods of the year, the ratio is greater, and the PV generator produces more energy than needed to operate the pump station. This excess energy can be directly consumed by other consumers in the UWS or delivered to a regional energy system. The excess energy can be stored in the reservoir as potential hydro energy or in batteries as electric energy for other users. There are various possibilities. The month with the highest water demand is the period that determines the required reservoir volume. It is usually the period with the highest heat/insolation and when water consumption is the highest. This is the period with the least required PV power, and the ratio $E_{S} / E_{H}$ is the most favorable. The problem of solar water pumping in an urban storm water system is even more complex because the inflow is stochastic, temporary, and very variable. Owing to this, it is difficult to expect that the storm water system could be directly integrated with an RES. The sustainable solution is an electric energy supply from a local smart grid, if available. 
Based on the above, it can be assumed that the use of solar energy and photovoltaic systems for water pumping in a UWS has good potential in a Water Supply System (WSS). By contrast, regarding a Waste Water System (WWS) or Storm Water System (SWS), direct application is not a complete solution. However, solar energy can be used successfully in all systems during the day (approximately 8-12 h), when electricity is the most expensive. During the night, lithium-ion battery storage or another local source of energy (biogas) or grid energy (commercial) can be used. This is a smart solution because it would yield very high security of the energy supply, better cost efficiency, and reduced $\mathrm{CO}_{2}$ emissions.

\section{SUMMARY AND CONCLUSION}

The application of a RES in a UWS is technologically feasible and desirable. Integrating renewable energy in an urban water system offers an alternative way toward sustainable development. This will contribute to the reduction of $\mathrm{CO}_{2}$ emissions and air pollution. Technological characteristics of the UWS enable the use of its own/internal RES, such as sludge from wastewater treatment plants (biogas) and hydraulic energy (mini-hydros) of the water supply system, and external global sources such as wind and solar energy. The use of an internal RES has become standard practice where it is technologically and economically feasible. Of all the local external RESs, the most suitable and long-term solution is the use of a photovoltaic system because of its wide availability, simplicity, and safety. Photovoltaics offer a practical and sustainable solution to the challenge of meeting the increasing UWS energy demand. It can be used as a local-only or main external source of energy or as a supplemental source of electric energy for the period of peak daily energy consumption in the UWS.

The most significant challenge is the effective balancing of production and consumption of energy, which is solved with an EES. Water storage in an urban water supply system can be used to balance the pumped water/energy input during sunlight periods and to output continuously in accordance with the water end energy demand, thus successfully replacing the use of other types of EES. Using water storage, it is possible to shift the energy demand and satisfy water supply needs. Reservoirs with proper sizing methodology, adapted to the use of solar energy for water pumping, provide a reliable water supply and also "smooth" the roughness of "raw" PV electricity. Given that water supply pumping is the biggest energy consumer, the sole use of a solar pumping system significantly affects the reduction of $\mathrm{CO}_{2}$ emissions as well as water conservation.

Continuous electric energy supply produced by a photovoltaic system for other electric energy demand in a UWS requires the application of an EES and appropriate grid network to integrate RES and UWS electric energy users. The proposed concept of PV and other RES integration in UWS cities achieves energy security and climate policy goals, energy independence, and security, as well as the reliability of water/energy services. With the expected increase in efficiency of photovoltaic systems $(>20 \%)$, the cost per kilowatt-hour will be reduced further by a factor of 2 to 3 and is therefore very suitable for UWS uses.

\section{References}

[1] Novotny, V. 2010: Urban water and energy use from current US use to cities of the future, Cities of the future/urban river restoration. Water Environmental Federation, https://doi.org/10.2175/193864710798285408

[2] Leitmann, J. 1999: Sustaining cities, McGraw-Hill. London, United Kingdom.

[3] UN, The Future We Wont: Rio 20+20, Outcome Document, www.uncsd2012.org/content/documents/ 727The\%20Future\%20We\%Want\%2019\%20June\%20123pm-pdf. Accessed on: 5 January 2014

[4] Water UK, Sustainability indicators 2010/11: www.water.org.uk/home/news/press-releases/indicators201011/water-uk---sustainability-report-2010-11.pdf. Accessed on: 10 January 2014

[5] Vachon, M. 2012: Nantes' and Oslo's urban water systems: Assessing benefits from water-energy nexus interventions, Report number D1-2012-36, NTNU-Trontheim, Norwegian University of Science and Technology.

[6] Judith, A.B. 2007: WATERGY: Energy and water efficiency in municipal water supply and wastewater treatment: Cost-effective savings of water and energy. Alliance to Save Energy, https://doi.org/10.1016/i.proeng.2015.08.952

[7] Academic press, 2009: Renewable energy focus handbook, Elsevier Inc. London, United Kingdom.

Margeta, J 
[8] Chen, H., Cong, T.N., Yang, W., Tan, C., Li, Y., Ding, Y. 2009: Progress in electrical energy storage system: A critical review. Progr. Nat. Sci., 19, 291-312, https://doi.org/10.1016/..pnsc.2008.07.014

[9] Kreider, J.F., Kreith, F. 2001: Solar energy handbook, McGraw-Hill, London. United Kingdom.

[10] Rulknes, W. 2008: Sewage sludge as a biomass resource for the production of energy: overview and assessment of the various options, Energy \& Fuels, 22, 9-15, http://dx.doi.org/10.1021/ef700267m

[11] McCharty, L.P., Bae, J., Kim, J. 2011: Domestic wastewater treatment as a net energy producer: Can this be achieved? Environmental Sci. Technol. 45, 7100, 10.1021/es2014264

[12] Owen, W.F. 1982: Energy in wastewater treatment. Prentice-Hall, New York.

[13] Logan, B.E. 2008: Microbial fuel cell. Wiley, New York.

[14] Armando, C., Giuseppe, D.G., Oreste, F., Helena M.R. 2013: Pump as turbine (PAT) design in water distribution network by system effectiveness. Water, 5, 1211-1225, https://doi.org/10.3390/w5031211

[15] European Small Hydropower Association (ESHA). 2010: Energy recovery in existing infrastructure with small hydropower plants: Multipurpose schemes, overview and examples.

[16] Powel, D.M., Winkler, M.T., Choi, H.J., Simmons, C.B., Needlemen, B.D., Buonassisi, T 2012: Crystalline silicon photovoltaic: A cost analysis framework for determining technology pathways to reach baseload electricity costs. Energy \& Environmental Science, 5, 5874-5883, 10.1039/C2EE03489A

[17] National Renewable Energy Laboratory (NREL). Efficiency records chart. Available online: http://www.nrel.gov/ncpv/images/efficiency_chart.jpg. Accessed on 10 August 2014.

[18] Djurin, B., Margeta, J. 2014: Analysis of possible use of solar photovoltaic energy in urban water supply systems. Water, 6, 1546-1561, https://doi.org/10.3390/w6061546

[19] Koroneos, K., Spachos, T., Moussiopoulos, N. 2003: Energy analysis of renewable energy sources. Renewable Energy, 28, 295-310, https://doi.org/10.1016/0301-4215(91)90060-2

[20] Kenna, J., Gillett, B. 1985: Solar water pumping: A handbook, Intermediate Technology Publications: London, United Kingdom.

Please cite this article as:

Margeta, J: A framework for application of renewable energy in urban water systems, Electronic Journal of the Faculty of Civil Engineering Osijek-e-GFOS, 16, pp. 1-10, https://doi.org/10.13167/2018.16.1 